\title{
Pengaruh Variasi Ukuran Bulir dan Waktu Aktivasi Terhadap Daya Serap Arang Tandan Aren Pada Iodium $\left(\mathrm{I}_{2}\right)$ dan Metilen Blue (MB)
}

\author{
Nuri Yanti ${ }^{1)}$, Muh. Anas ${ }^{2)}$, Rosliana Eso ${ }^{2)}$ \\ ${ }^{1)}$ Alumni Jurusan Pendidikan Fisika FKIP UHO, Kendari, Sulawesi Tenggara, Indonesia 93232 \\ ${ }^{2,)}$ Dosen Jurusan Pendidikan Fisika FKIP UHO, Kendari, Sulawesi Tenggara, Indonesia 93232 \\ Email: nuriyanti.Prianto@gmail.com
}

\begin{abstract}
This study was motivated by palm sugar bunches waste which has not been handled well. One method that can be used to remove pollutants from wastewater is adsorption. The material commonly used as an absorber is activated charcoal. This study aims to know the effect of grain size variation and activation time on the capacity adsorption on Iodine and Methylene Blue activated charcoal from palm sugar bunches. This research is an experimental research. The sample in this study was activated charcoal which has varying grain sizes of 60 mesh, 100 mesh and 200 mesh and is activated at a temperature of $7000 \mathrm{C}$ and the activation time varies from 60 minutes, 90 minutes and 120 minutes. The iodine adsorption power test uses the Iodimetry Titration Method, while the Metile Blue adsorption test uses UV-Vis Spectrophotometry. The results showed that the adsorption power of Iodine and Methylene Blue was maximum at 448,38 $\mathrm{mg} / \mathrm{g}$ and $117,744 \mathrm{mg} / \mathrm{g}$.
\end{abstract}

Keywords: Grain Size, Activation Time, Iodine Capacity Adsorption, Methylene Blue Capacity Adsorption, and Palm Sugar Bunch.

\begin{abstract}
Abstrak: Penelitian ini dilatarbelakangi dengan adanya limbah tandan aren yang sampai saat ini belum dapat ditangani dengan baik. Salah satu metode yang dapat digunakan untuk menghilangkan zat pencemar dari air limbah adalah adsorpsi. Material yang biasa digunakan sebagai penyerap yaitu arang aktif. Penelitian ini bertujuan untuk mengetahui pengaruh variasi ukuran bulir dan waktu aktivasi terhadap daya adsorpsi Iodium dan Metilen Blue dari arang aktif tandar aren. Penelitian ini merupakan penelitian Eksperimen. Sampel dalam penelitian ini adalah arang aktif yang memiliki variasi ukuran bulir 60 mesh, 100 mesh dan 200 mesh dan diaktivasi dengan temperatur $700^{\circ} \mathrm{C}$ serta waktu aktivasi yang bervariasi yaitu 60 menit, 90 menit dan 120 menit. Uji daya adsorpsi Iodium menggunkan Metode Titrasi Iodimetri, sedangkan uji adsorpsi Metile Blue menggunakan Spektrofotometri UV-Vis. Hasil penelitian menunjukan bahwa daya adsorpsi Iodium dan Metilen Blue maksimum pada ukuran partikel 200 mesh dengan waktu aktivasi 120 menit yaitu masing-masing sebesar 448,38 mg/g dan $117,744 \mathrm{mg} / \mathrm{g}$.
\end{abstract}

Kata Kunci: Ukuran Bulir, Waktu Aktivasi, Daya Adsorpsi Iodium, Daya Adsorpsi Metilen Blue, dan Tandan Aren.

\section{PENDAHULUAN}

Aren (Arenga pinnata) termasuk salah satu jenis tanaman palma, yang tersebar hampir di seluruh wilayah Indonesia, terutama di 14 provinsi yaitu Papua, Maluku, Maluku Utara, Sumatera Utara, Sumatera Barat, Jawa barat, Jawa Tengah, Banten, Sulawesi Utara, Sulawesi Selatan, Sulawesi Tenggara, Bengkulu, Kalimantan Selatan, dan Aceh, dengan total luas areal sekitar 70.000 Ha. Tanaman aren tidak membutuhkan kondisi tanah yang spesifik, sehingga dapat tumbuh pada tanah-tanah liat, dan berpasir, tetapi aren tidak tahan pada tanah masam ( $\mathrm{pH}$ tanah yang rendah). Aren dapat tumbuh pada ketinggian 01.400 meter di atas permukaan laut, pada berbagai agroekosistem dan mempunyai daya adaptasi yang tinggi terhadap lingkungan tumbuhnya (Suswono, 2014). 
Masyarakat selama ini hanya memanfaatkan tandan aren sebagai bagian pembuat nira aren tanpa pengolahan lebih lanjut, namun ada kegunaan lain dari tandan aren yang juga penting yaitu sebagai arang aktif. Arang aktif adalah senyawa yang berbentuk amorf yang dapat dihasilkan dari arang yang diperlakukan secara khusus untuk memperluas permukaan arang dengan membuka poripori yang tertutup sehingga daya adsorpsinya lebih tinggi (Hasminar, 2014).

Beberapa penelitian tentang pemanfaatan tandan aren sebagai arang aktif telah dilakukan diantaranya, Arjulita Sari (2019), hasil penelitiannya tentang daya serap arang aktif dari tandan aren dengan memvariasikan temperatur aktivasi arang tandan aren tersebut menunjukkan bahwa penyerapan terhadap iodium $\left(\mathrm{I}_{2}\right)$ sebesar 364,43 mg/g dan terhadap metilen blue (MB) sebesar $67,84 \mathrm{mg} / \mathrm{g}$ pada temperatur $700^{\circ} \mathrm{C}$. Sri Wahyuni (2018), hasil penelitiannya tentang arang aktif cangkang kelapa sawit dengan memvariasikan temperatur aktivasi arang cangkang kelapa sawit tersebut menunjukkan bahwa penyerapan maksimumnya yaitu terhadap iodium $\left(\mathrm{I}_{2}\right)$ sebesar 312,922 mg/g dan terhadap metilen blue (MB) sebesar $71,33 \mathrm{mg} / \mathrm{g}$ pada temperatur $750^{\circ} \mathrm{C}$. Hasil yang didapatkan ini belum mencapai nilai Standar Industri Indonesia untuk syarat mutu arang aktif yaitu daya serap terhadap iodium $750 \mathrm{mg} / \mathrm{g}$ dan daya serap terhadap metilen blue yaitu $120 \mathrm{mg} / \mathrm{g}$. Hal ini dikarenakan masih adanya zat pengotor yang menyumbat pori karbon sehingga jumlah pori semakin kecil dan temperatur yang tinggi berpengaruh pada struktur dari arang sendiri sehingga menjadi rapuh akibat adanya pengikisan sehingga luas permukaan rongga arang aktif menjadi dangkal.

Faktor-faktor yang mempengaruhi daya serap arang aktif yaitu sifat adsorben, sifat serapan, temperatur, $\mathrm{pH}$ (derajat keasaman), ukuran partikel, dan waktu aktivasi (Kardivelu, 2003). Pada penelitian ini, peneliti menggunakan dua faktor yang dapat mempengaruhi daya serap yaitu ukuran partikel dan waktu aktivasi karena makin besar ukuran mesh jumlah partikel semakin besar maka luas permukaan penyerapan juga semakin. Sementara itu, pada waktu aktivasi yang makin lama mengakibatkan banyak zat inert di permukaan partikel arang yang terlepas dari permukaan sehingga pori-pori permukaan pertikel karbon aktif makin banyak (Maulida, 2019). Kedua hal di atas mengakibatkan kemampuan daya serappun meningkat.

Berdasarkan uraian di atas, maka peneliti merasa penting untuk mencari perbaikan atas penelitian yang telah dilakukan sebelumnya agar dapat menghasilkan daya serap yang lebih tinggi dengan melakukan variasi pada ukuran bulir dan waktu aktivasi karena sangat berpengaruh pada daya serap, semakin kecil ukuran partikel akan semakin cepat proses adsorpsi dan dengan variasi waktu aktivasi, maka larutan yang memiliki viskositas tinggipun dapat mendapatkan hasil adsorpsi yang baik dengan memperlama waktu aktivasi, penelitian ini berjudul "Pengaruh Variasi Ukuran Bulir dan Waktu Aktivasi terhadap Daya Serap Arang Tandan Aren pada Iodium $\left(\mathrm{I}_{2}\right)$ dan Metilen Blue (Mb)".

\section{METODE}

Penelitian ini merupakan jenis penelitian dalam bidang fisika material dengan menggunakan metode eksperimen. Penelitian ini dilaksanakan pada 11 September 2019 sampai 5 Oktober 2019. Adapun tempat pelaksanaannya yaitu :

- Proses pengambilan tandan aren diperoleh dari desa Abeli, Kecamatan Abeli, Kota Kendari, sulawesi tenggara.

- Karbonasi, penggerusan dan pengayakan sampel dilakukan di sekitaran kampus UHO.

- Aktivasi sampel dilakukan di Laboratorium Kimia FKIP. 
- Pengambilan sampel air keruh diperoleh dari sungai Wanggu Kendari.

- Analisis dilakukan di Laboratorium Kimia FMIPA UHO.

\section{Alat dan Bahan}

Alat dan bahan yang akan digunakan pada penelitian ini dapat dilihat pada tabel berikut:

Tabel 1. Alat dan Bahan Penelitian

\begin{tabular}{|c|c|c|c|c|}
\hline No & Nama Alat/Bahan & Spesifikasi & NST & Fungsi \\
\hline 1. & Reaktor pirolisis & & & Mengkarbonasi tandan aren \\
\hline 2. & Tanur Pengaktif & $\begin{array}{l}\text { ELF 11/14B } \\
\text { Max. } 1100^{\circ} \mathrm{C} \\
\end{array}$ & & Mengaktivasi sampel \\
\hline 3. & Kemasan Plastik & - & - & $\begin{array}{l}\text { Wadah penyimpanan sampel } \\
\text { arang aktif }\end{array}$ \\
\hline 4. & Tembangan Digital & $0,1 \mathrm{mg}$ & - & $\begin{array}{l}\text { Mengukur massa dari arang } \\
\text { aktif }\end{array}$ \\
\hline 5. & Erlenmeyer & $0-50 \mathrm{Ml}$ & $10 \mathrm{ml}$ & Wadah melarutkan Arang aktif \\
\hline 6. & Gelas Ukur & $0-100 \mathrm{Ml}$ & $10 \mathrm{ml}$ & $\begin{array}{l}\text { Wadah menyimpan air iodium } \\
\text { dan metilen blue }\end{array}$ \\
\hline 7. & Desikator & - & - & Mendinginkan sampel \\
\hline 8. & Ayakan & $\begin{array}{c}\text { 60, } 100 \text { dan } 200 \\
\text { mesh }\end{array}$ & - & Menyeragamkan ukuran partikel \\
\hline & $\begin{array}{l}\text { Termometer } \\
\text { Infrared }\end{array}$ & $\begin{array}{c}\text { Rosewil } \\
\text { REGDTN439LO }\end{array}$ & - & $\begin{array}{l}\text { Mengukur temperatur } \\
\text { karbonisasi }\end{array}$ \\
\hline 10. & $\begin{array}{l}\text { Tumpang Alu dan } \\
\text { Mortar }\end{array}$ & - & 1 buah & Menggerus sampel \\
\hline 11. & Kertas saring & Whatmann 42 & - & Sebagai penyaring \\
\hline & $\begin{array}{l}\text { Spektrofotometer } \\
\text { UV-Vis }\end{array}$ & $190-1.100 \mathrm{~nm}$ & - & $\begin{array}{l}\text { Mengukur daya serap arang } \\
\text { aktif Tandan Aren dalam larutan } \\
\text { Metilen Blue }\end{array}$ \\
\hline & Tandan Aren & - & - & Bahan arang aktif \\
\hline & $\begin{array}{l}\text { Iodium, Metilen } \\
\text { Blue dan air sungai }\end{array}$ & - & - & Bahan pengamatan \\
\hline & Parang & - & 1 Buah & Memotong tandan aren \\
\hline & Air & - & - & Membersihkan tandan aren \\
\hline 17. & Aquades & - & - & Bahan pembuat larutan \\
\hline 18. & Cawan & - & 9 buah & Wadan saat mengaktifasi \\
\hline & Alkohol & $70 \%$ & 1 botol & $\begin{array}{l}\text { Membersihkan wadah } \\
\text { penggerus }\end{array}$ \\
\hline & $\begin{array}{l}\text { Tabung } \\
\text { Sentrifugasi }\end{array}$ & $\begin{array}{c}4500 \text { dan } 20 \\
\text { menit }\end{array}$ & & $\begin{array}{l}\text { Untuk mangendapkan arang } \\
\text { aktif di dasar }\end{array}$ \\
\hline & Batang Pengaduk & & 1 buah & Untuk mengaduk larutan \\
\hline & $\mathrm{pH}$ meter & & 1 buah & Untuk mengukur $\mathrm{pH}$ air sungai \\
\hline
\end{tabular}




\section{Prosedur Kerja}

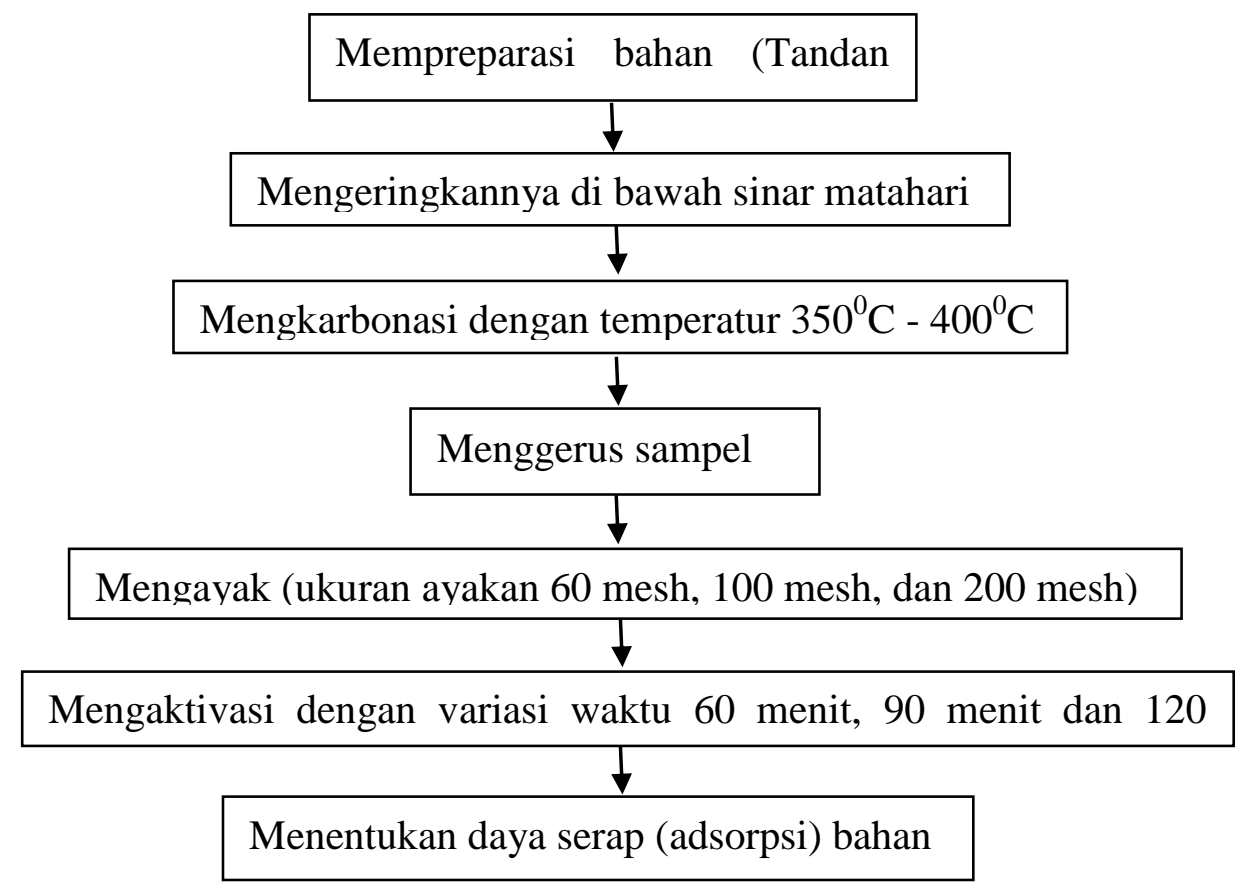

Gambar 1. Bagan Alir Prosedur Kerja Penelitian

Adapun langkah kerja yang akan dilakukan pada penelitian ini yaitu sebagai berikut:

a. Pembuatan arang aktif

- Menyiapkan tandan aren, kemudian memotongnya menjadi beberapa bagian.

- Mencuci tandan aren dari debu dan partikel kotor lainnya dengan menggunakan aquades.

- Mengeringkan tandan aren di bawah sinar matahari.

- Mengkarbonasi tandan aren menggunakan reaktor pirolisis selama \pm 8 jam dengan temperatur $320^{\circ} \mathrm{C}-400^{\circ} \mathrm{C}$ sampai menghasilkan arang.

b. Penggerusan dan Pengayakan

- Menggerus sampel dengan menggunakan tumpang alu dan mortar yang telah dibersihkan dengan menggunakan alkohol.

- Mengayak sampel dengan menggunakan ayakan bertingkat yaitu 60 mesh, 100 mesh, dan 200 mesh sehingga diperoleh bubuk tandan aren yang bervariasi.

- Mambagi arang menjadi tiga bagian dimana setiap bagian terdiri dari sampel ukuran 60 mesh, 100 mesh dan 200 mesh yang beratnya masingmasing 10 gram.

c. Pengaktivasian Sampel

- Mengaktivasi sampel menggunakan tanur listrik dengan temperatur $700^{\circ} \mathrm{C}$ dan waktu aktivasi yang bervariasi yaitu 60 menit untuk bagian sampel pertama, 90 menit untuk bagian sampel kedua, dan 120 menit untuk bagian sampel ketiga.

- Masukkan sampel ke dalam kemasan plastik kecil sesuai dengan label masing-masing.

- Siapkan sampel untuk dianalisis.

d. Analisis daya serap arang aktif tandan aren

1) Uji daya serap terhadap iodium

- Hasil arang aktif yang telah diaktivasi masing-masing ditimbang sebanyak 3 gram dan dimasukkan ke dalam erlenmeyer. 
- Campur sampel dengan $100 \mathrm{ml}$ larutan iodium $0,1 \mathrm{~N}$ lalu aduk larutan selama 4 menit.

- Memindahkan larutan ke dalam tabung sentrifugasi sampai arang aktif turun dan mengendap di dasar.

- Mengambil $10 \mathrm{ml}$ cairan itu dan lakukan proses titrasi dengan larutan $\mathrm{Na}_{2} \mathrm{~S}_{2} \mathrm{O}_{3} \quad 0,1 \quad \mathrm{~N}$ hingga terbentuk warna kuning.

- Mengamati perubahan warna pada larutan yang telah tercampur dengan arang aktif dan larutan $\mathrm{Na}_{2} \mathrm{~S}_{2} \mathrm{O}_{3}$ (Natrium Tiosulfat).

- Jika warna kuning mulai samar, tambahkan $2 \mathrm{ml}$ larutan amilum 1 $\%$ sebagai indikator.

- Lakukan analisis untuk menentukan daya serap terhadap iodium.

2) Uji daya serap terhadap metilen blue

- Timbang masing-masing arang aktif yang telah di aktivasi dengan massa 0,03 gram.

- Masukkan arang aktif ke dalam erlenmeyer yang berbeda-beda.

- Tambahkan larutan metilen blue dengan konsentrasi $50 \mathrm{mg} / \mathrm{L}$ ke dalam masing-masing erlenmeyer sebanyak $100 \mathrm{ml}$ dan kocok larutan selama 4 menit.

- Diamkan selama 4 menit, kemudian pisahkan residu dan fitrat melalui penyaringan dengan menggunakan kertas saring.

- Ukur absorbansinya dengan menggunakan spektofotometri Uv-Vis pada panjang gelombang $665 \mathrm{~nm}$ untuk mengetahui kosentrasi larutan yang tidak terserap (residu).

- Lakukan analisis untuk menentukan daya serap terhadap larutan metilen blue.

3) Pembuatan kurva standar larutan metilen blue
- Membuat larutan standar metilen blue dengan kosentrasi $50 \mathrm{mg} / \mathrm{L}$, $40 \mathrm{mg} / \mathrm{L}, 30 \mathrm{mg} / \mathrm{L}, 20 \mathrm{mg} / \mathrm{L}, 10$ $\mathrm{mg} / \mathrm{L}$ dan $5 \mathrm{mg} / \mathrm{L}$.

- Masing-masing larutan standar metilen blue tersebut diukur absorbansinya menggunakan spektrofotometer UV-Vis pada panjang gelombang $665 \mathrm{~nm}$.

- Membuat kurva standar metilen blue dengan memplot absorbansi sebagai sumbu y dan konsentrasi metilen blue sebagai sumbu $\mathrm{x}$ sehingga diperoleh persamaan garis regresi linear.

e. Arang aktif tandan aren sebagai penjernihan air keruh sungai wanggu

- Memasukkan $100 \mathrm{ml}$ sampel air keruh ke dalam erlenmeyer.

- Mengamati warna sampel air keruh, bau dan ukur $\mathrm{pH}$ sampel dengan menggunakan $\mathrm{pH}$ meter.

- Kemudian menambahkan $5 \mathrm{~g}$ komposit arang aktif tandan aren yang memiliki daya serap iodium dan metilen blue optimum.

- Mengaduk campuran sampai homogen dengan menggunakan magnetic stirer.

- Menyaring sampel air dan komposit tadi dengan menggunakan kertas saring, yang bertujuan untuk memisahkan komposit dengan air yang telah diserap.

- Air hasil saringan tersebut kemudian dianalisa kualitasnya yaitu mengamati secara fisik perubahan warna pada sampel air sungai setelah difiltrasi, bau, dan mengukur $\mathrm{pH}$ air dengan menggunakan $\mathrm{pH}$ meter.

\section{Analisis Data Penentuan Uji Adsorpsi} Arang Aktif

- Daya serap arang aktif terhadap Iodium $\left(\mathrm{I}_{2}\right)$

$$
I\left(\frac{m g}{g}\right)=\frac{\left(V_{2} N_{2}\right) \cdot 126,9 \cdot f p}{\left(V_{1} N_{1}\right) \cdot W}
$$


Keterangan :

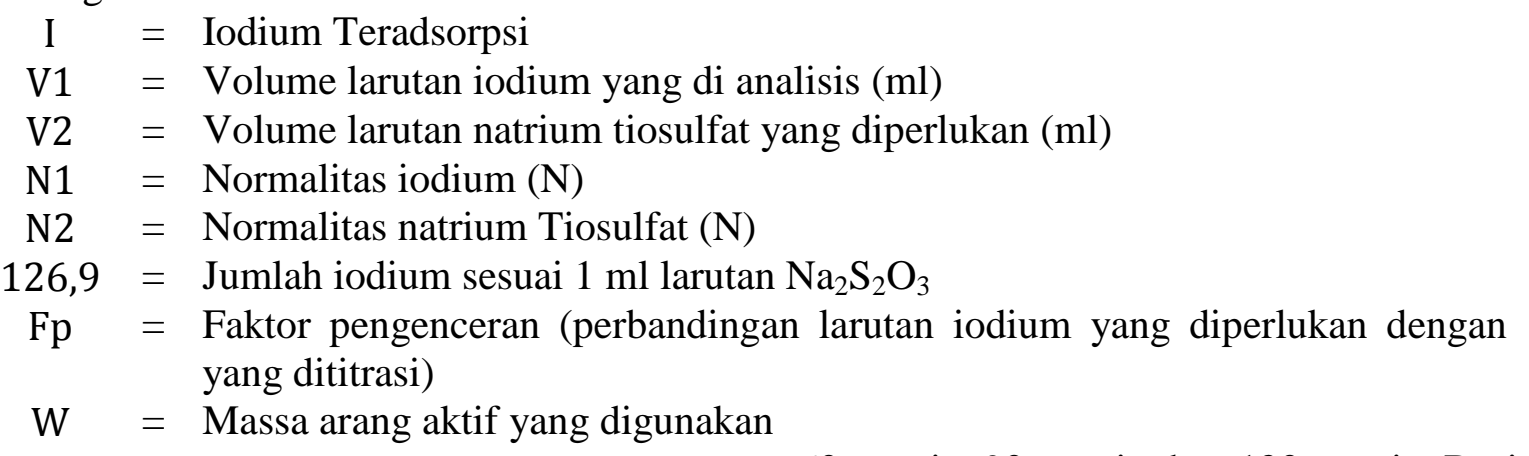

- Daya serap arang aktif terhadap Metilen Blue (MB)

$$
W_{m b}=\frac{M_{b} \text { setimbang }}{W} V
$$

- Tabel daya serap arang aktif terhadap Iodium.

- Grafik hubungan antara daya serap Iodium dengan variasi ukuran bulir dan waktu aktivasi.

- Tabel daya serap arang aktif terhadap Metilen Blue.

- Grafik hubungan antara daya serap Metilen Blue dengan variasi ukuran bulir dan waktu aktivasi

- Tabel data dan kurva Kalibrasi larutan metilen blue pada panjang gelombang maksimum $665 \mathrm{~nm}$.

- Analisis perubahan fisik, bau dan pH penjernihan air keruh sungai wanggu oleh arang aktif tandan aren.

\section{HASIL DAN PEMBAHASAN}

Penelitan ini menghasilkan produk serbuk arang aktif tandan aren dengan variasi ukuran bulir 60 mesh, 100 mesh dan 200 mesh serta variasi waktu aktivasi
60 menit, 90 menit dan 120 menit. Dari penelitian ini dapat diketahui bagaimana pengaruh ukuran bulir dan waktu aktivasi terhadap daya adsorpsi Iodium dan Metilen Blue dari arang aktif tandan aren. Iodin atau Iodium (bahasa Yunani: Iodes ungu), adalah unsur kimia pada tabel periodik yang memiliki simbol I dan nomor atom 53. Unsur ini diperlukan oleh hampir semua mahkluk hidup. Iodin adalah halogen yang reaktivitasnya paling rendah dan paling bersifat elektropositif. Metilena biru (CI 52015) adalah senyawa kimia aromatik heterosiklik dengan rumus kimia $\mathrm{C}_{16} \mathrm{H}_{18} \mathrm{~N}_{3} \mathrm{SCl}$. Senyawa ini banyak digunakan pada bidang biologi dan kimia. Pada suhu ruangan senyawa ini berbentuk padatan, tak berbau, berbentuk bubuk warna hijau tua yang akan menghasilkan larutan warna biru tua bila dilarutkan dalam air. Bentuk hidratnya mengandung 3 molekul air per molekul metilena biru (Mastah, 2019).

\section{Iodium}

Hasil analisis daya adsorpsi Iodium terhadap arang aktif dengan variasi ukuran bulir dan waktu aktivasi dapat dilihat pada tabel berikut:

Tabel 2. Daya serap Iodium terhadap Arang Aktif

\begin{tabular}{lcccc}
\hline \multirow{2}{*}{ No } & \multirow{2}{*}{ Ukuran Bulir (mesh) } & \multicolumn{3}{c}{ Daya Serap (mg/g) } \\
\cline { 2 - 5 } & 60 & $\mathbf{6 0}$ menit & $\mathbf{9 0}$ menit & $\mathbf{1 2 0}$ menit \\
\hline 1 & 100 & 211,5 & 211,5 & 232,65 \\
\hline 3 & 200 & 317,25 & 317,25 & 359,55 \\
\hline & & 423 & 431,46 & 448,38 \\
\hline
\end{tabular}




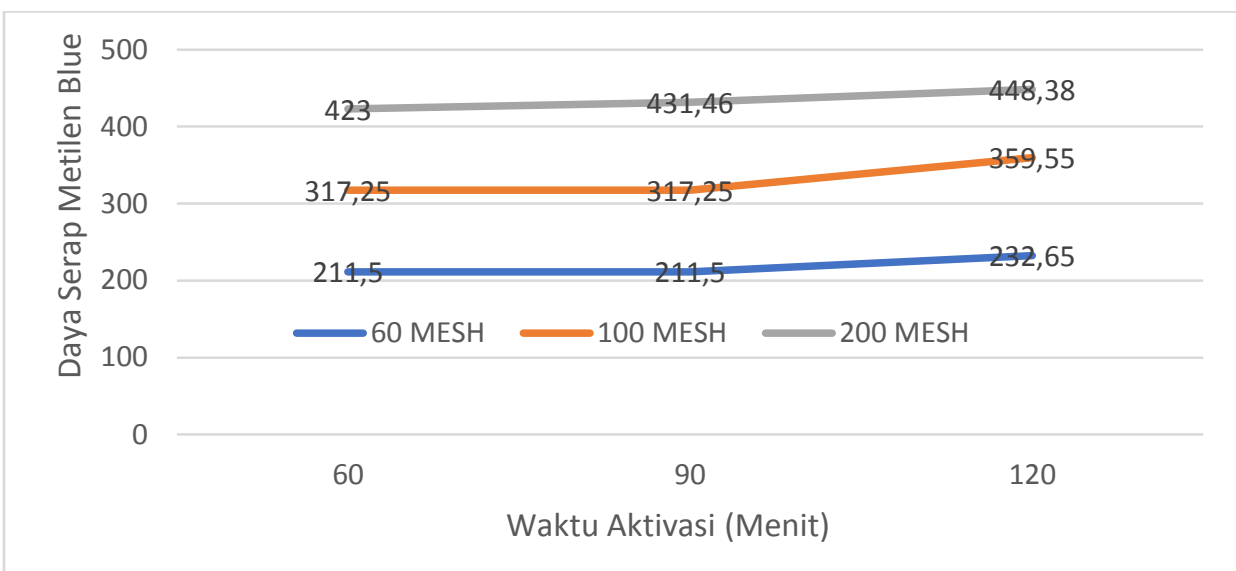

Gambar 2. Grafik Hubungan Antara Daya Serap Iodium dengan Variasi Ukuran Bulir dan Waktu Aktivasi Arang Aktif

Daya adsorpsi iodium memiliki kemampuan dalam menyerap molekulmolekul yang berukuran kecil (mikropori) sehingga lebih mudah terlepas dari pori arang aktif yang lebar. Hal ini menyebabkan daya adsorpsi iodium tidak memenuhi SNI (Ranada 2015). Pengukuran daya adsorpsi Iodin dilakukan dengan metode titrasi Iodimetri. Hasil yang diperoleh menunjukkan bahwa daya serap Iodium secara umum menunjukkan peningkatan seiring dengan bertambah tingginya nilai mesh dan lama aktifasi, hal ini menunjukkan bahwa semakin tinggi nilai mesh dan semakin lama waktu aktifasi, maka semakin banyak pori-pori arang aktif yang terbuka membentuk rongga yang lebih besar ukurannya dari molekul Iodium sehingga molekul Iodium masuk kedalam rongga arang aktif. Salah satu parameter yang diuji dan menjadi acuan kualitas arang aktif ialah daya serap Iodium, semakin tinggi daya serap Iodium, maka semakin tinggi mutu/kualitas arang aktif, karena penggunaan arang aktif umumnya sebagai bahan penyerap (absorpsi). Daya adsorpsi arang aktif terhadap iodium memiliki korelasi dengan luas permukaan dari arang aktif. Semakin besar angka iodium maka semakin besar kemampuannya dalam mengadsorpsi adsorbat atau zat terlarut. Luas area permukaan pori merupakan suatu parameter yang sangat penting dalam menentukan kualitas dari suatu arang aktif sebagai adsorben. Hal ini disebabkan karena luas area permukaan pori merupakan salah satu faktor yang mempengaruhi daya adsorpsi dari suatu adsorben (Pari, 2006).

\section{Metilen Blue}

\section{Analisis daya adsorpsi Metilen Blue}

Hasil analisis daya adsorpsi Iodium terhadap arang aktif dengan variasi ukuran bulir dan waktu aktivasi dapat dilihat pada tabel berikut:

Tabel 3. Daya Serap Metilen Blue terhadap Arang Aktif

\begin{tabular}{ccc}
\hline Ukuran Partikel (Mesh) & Waktu Aktivasi (Menit) & $\mathbf{W}_{\text {ads }}$ (mg/g) \\
\cline { 2 - 3 } 6 & 60 & 66,426 \\
\cline { 2 - 3 } 60 & 90 & 76,436 \\
\cline { 2 - 3 } & 120 & 80,440 \\
\cline { 2 - 3 } 100 & 60 & 103,463 \\
\hline \multirow{2}{*}{100} & 90 & 105,666 \\
\hline
\end{tabular}




\begin{tabular}{lcc}
\hline & 120 & 106,967 \\
\hline \multirow{2}{*}{200} & 60 & 112,472 \\
\cline { 2 - 3 } & 90 & 115,375 \\
\cline { 2 - 3 } & 120 & 117,477 \\
\hline
\end{tabular}

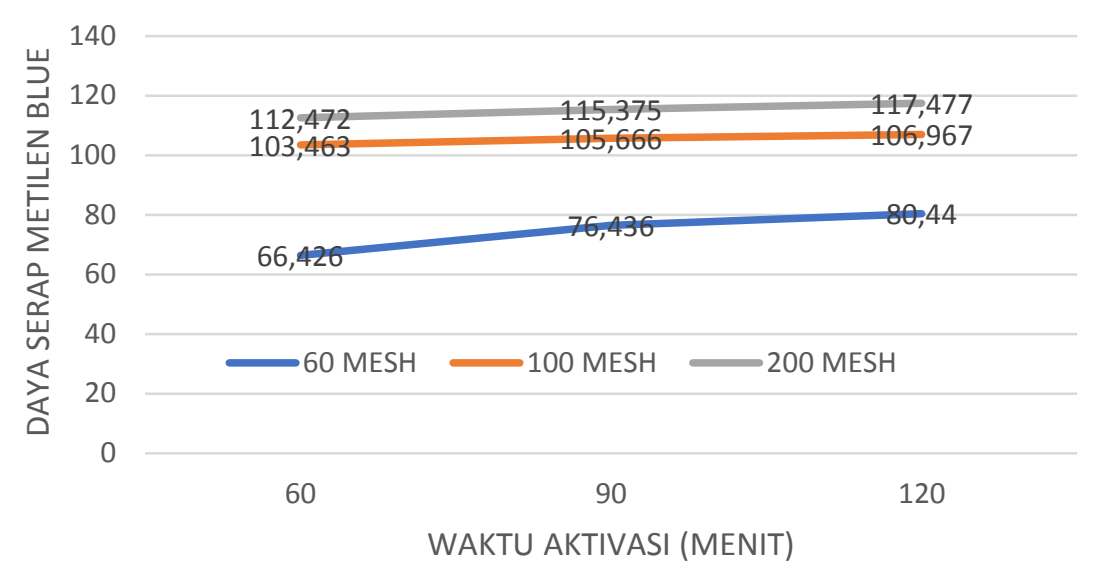

Gambar 3. Grafik Hubungan Antara Daya Serap Metilen Blue dengan Variasi Ukuran Bulir dan Waktu Aktivasi Arang Aktif

Pengukuran daya adsorpsi Metilen Blue dilakukan dengan kurva kalibrasi dari variasi kosentrasi larutan standar Metilen Blue dan diukur menggunakan Spektrofotometri UV-Vis. Hasil yang diperoleh menunjukkan bahwa semakin tinggi kosentrasi (ppm), maka nilai absorbansi (A) juga semakin besar sehingga kurva yang terbentuk bersifat linear. Hal ini disebabkan karena kosentrasi yang semakin tinggi mengakibatkan semakin banyak sinar Uv dari spektrfotometri yang dapat diserap oleh molekul-molekul dalam larutan yang konstan sehingga arang aktif mengalami kejenuhan dan tidak terjadi lagi perpindahan massa dari makropori ke mikropori. Parameter lain yaitu luas permukaan absorben yang memiliki sifat homogen serta menunjukkan adanya permukaan yang mempunyai sifat heterogen. Berdasarkan lampiran tersebut, terlihat grafik salah satu hubungan antara ukuran bulir dan waktu aktivasi terhadap daya adsorpsi Metilen Blue dari arang aktif tandan aren pada gambar 3. dari grafik tersebut terlihat kurva bersifat linear, dimana semakin tinggi ukuran mesh dan waktu aktivasi arang aktif maka daya adsorpsi metilen blue semakin tinggi pula. Pada ukuran bulir 200 mesh dengan waktu aktivasi 120 menit daya adsorpsi memenuhi SNI dan memiliki nilai yang baik, hal ini dipengaruhi oleh ukuran rongga pori yang terbentuk pada saat aktivasi terbilang besar untuk menampung molekul dengan ukuran pori Metilen Blue. Hal ini sekaligus menandayakan daya adsorpsi Metilen Blue berada dalam rentang mesopori (Pari, 2003).

Penjernihan Air Sungai

Penjernihan air sungai ini dilakukan dengan menggunakan arang aktif yang memiliki daya serap maksimum atau paling tinggi terhadap Iodiun dan Metilen Blue. Analisis perubahan fisik, bau dan $\mathrm{pH}$ air keruh yang diperoleh dari air sungai wanggu dapat dilihat pada tabel berikut : 
Tabel 4. Analisis Perubahan Fisik Air Keruh Sungai Wanggu

\begin{tabular}{cccc}
\hline \multirow{2}{*}{ No } & \multirow{2}{*}{ Analisis } & \multicolumn{2}{c}{ Pengaplikasian Arang AKtif } \\
\cline { 3 - 4 } & Warna & Keruh/kecoklatan & Sesudah \\
\hline 1 & Bau & Berbau & Jernih \\
\hline 2 & $\mathrm{pH}$ & 5,06 & Tidak Berbau \\
\hline 3 & & & 7,3 \\
\hline
\end{tabular}

Arang aktif dapat mengurangi tingkat kekeruhan, bau dan $\mathrm{pH}$ air, warna dan bau diamalisis dengan mengamati perubahan air sungai sebelum dan setelah diberi arang aktif dan hasilnya yaitu warna keruh pada air berubah menjadi jernih dan bau pada air menghilang. $\mathrm{pH}$ air sebelum dan sesudah diberi arang aktif diukur menggunakan $\mathrm{pH}$ meter. $\mathrm{pH}$ adalah derajat keasaman yang digunakan untuk menyatakan tingkat keasaman dan kebasahan yang dimiliki oleh suatu larutan. Nilai $\mathrm{pH}$ di bawah 7 bersifat asam dan nilai $\mathrm{pH}$ di atas 7 bersifat basa. Air yang bersifat asam dapat menyebabkan gatal-gatal, diare dan kulit bersisik (Hysocc, 2013). Berdasarkan hasil yang diperoleh, dengan penambahan arang aktif terjadi penambahan nilai $\mathrm{pH}$ yang cukup tinggi, dengan demikian selain digunakan sebagai penyerap arang aktif juga dapat digunakan untuk menaikkan nilai $\mathrm{pH}$ pada air. Dapat dikatakan proses filtrasi dengan menambahkan arang aktif cukup baik untuk memperbaiki kualitas air yang bersifat asam, karena dapat membuat air tersebut memenuhi $\mathrm{pH}$ standar air $(7,0-$ $7,5)$.

\section{KESIMPULAN}

Berdasarkan hasil yang telah diperoleh dari penelitian ini, maka dapat disimpulkan bahwa:

1. Terdapat kecenderungan terjadi peningkatan daya serap dari mesh partikel kecil ke ukuran partikel yang lebih besar, pada mesh kecil berarti jumlah partikel sedikit maka luas permukaan penyerapan kecil, sedangkan makin besar ukuran mesh jumlah partikel semakin besar maka luas permukaan penyerapan juga semakin besar sehingga kemampuan daya serap juga makin besar.

2. Waktu aktivasi yang tidak terlalu lama menyebabkan aktivator hanya mampu membuka pori-pori patrikel karbon sedikit maka daya serap karbon aktifpun rendah, sedangkan makin lama waktu aktivasi maka makin banyak zat inert di permukaan partikel arang yang terlepas dari permukaan sehingga pori-pori permukaan pertikel karbon aktif makin banyak menyebabkan luas permukaan semakin besar dan kemampuan daya serapun meningkat.

\section{DAFTAR PUSTAKA}

Agusta, M. 2012. Kajian Struktur Arang Aktif terhadap Daya Adsorpsi. IPB. Bogor

Ahmaruzzman, Md. 2008. Adsorption of Phenolic compounds on Low-Cost Adsorbents: A review, Adv. Coll. Interf. Sci. Vol. 143, Hal. 48-67.

Anonim. 2012. Activated Carbon Technologies. Chemviron Carbon Corporation U.S.A.

Atkins, P, W. 1997. Kimia Fisik. Edisi ke4. Irma IK. Penerjemah, Jakarta: Erlangga. Terjemahan dari: Physical Chemistry.

Baksh. 1992. Characterization by Physisorption of a New Class of Microporous Adsorbents Pillared Clays, ind. Eng. Chem. Res., 31; 2181-2189.

Hamdaoui, O. Chiha, M. 2006. Removal of Methylene blue from 
AqueousSolutions. by Wheat Bran, Acta Chim. Slov., 54, 407-418

Hasminar. 2014. Analisis Pengaruh Temperatur Aktivasi Terhadap Gugus Fungsional dan Daya Adsorpsi Arang Aktif Kulit Biji dengan Agen Aktivasi $\mathrm{N}_{2}$. Jurusan Fisika FMIPA Universitas Halu Oleo. Kendari.

Houston, D. Frianda. 1972. Rice Bran and Polish. In: Rice: Chemistry \& Technology, 1stEd. Amer: Assoc. Cereal Chem. Inc., St. Paul, Minnesota, USA. P.272300

Hysocc. 2013. pH (Derajat Keasaman). http://id.m.wikipedia.

Kardivelu, K, M. Kavipriya, C. Karthika, M. Vennilamani, N, and Pattabhi, S. 2003. Utilization of Various Agricultural Wastes for Aktivated Carbon Preparation on Aplication for The Removal of Dyes and Metal Ions from Aquoeous Solutions. Bioresource Thecnology. Pp. 1-2.

Khopkar, S, M. 2003. Konsep Dasar Kimia Analitik. UIPress. Jakarta.

Kundari, N. A, dan Wiyuniati, S. 2008. Tinjauan Kesetimbangan Adsorpsi Tembaga dan Limbah Pencuci PCB dengan Zeolit. Seminar Nasional IV SDM Teknologi Nuklir. 25-26 Agustus 2008. Yogyakarta.

Maulida, I, L. 2019. Pengaruh Waktu Aktivasi dan Diameter Partikel pada Karbon Aktif dari Pelepah aren (Arenga pinnata) dengan Aktivator $\mathrm{H}_{3} P O$. Tekhnik Kimia Universitas Muhammadiyah Surakarta. Surakarta.

Marsh, H, dan Fransisco, R, R. 2006. Aktivated Carbon. Elsivier Science and Technology Books. Ukraina.

Melita, T. S, dan Tuti, S. 2003. Arang Aktif Pengenalan dan Proses Pembuatannya. www.library.usu.ac.id.

Murti, S. 2008. Pembuatan Karbon Aktif dari Tongkol Jagung untuk Adsorpsi
Molekul Amonia dan Ion Krom. Departemen Tekhnik Kimia FTUI. Depok.

Reynolds, T. D. 1982. Unit Operations and Processes in Enviromental Enginering. Brooks/Cole Enginering Division Monterey: California.

Sari, A. 2019. Daya Serap Arang Aktif Tandan Aren Terhadap Iodin dan Metilen Blue. Jurusan Pendidikan Fisika FKIP Universitas Halu Oleo. Kendari.

Sembiring, Meilita, T, dan Tuti, S. S. 2003. Arang Aktif, Pengenalan dan Proses Pembuatannya. Universitas Sumatera Utara. Medan.

Trisna, B. Milawan, M. Indah. Naimatul, K. Eko, S. 2017. Optimasi Penggunaan Biosorbent Berbasis Biomassa : Pengaruh Kosentrasi Activator terhadap Luas Permukaan Karbon Aktif berbahan Enceng Gondok (EICHORNIA CROSSIPES)untuk Meningkatkan Kualitas Air, Jurnal Tekhnik Mesin (JTM) : Vol. 6, edisi spesial. Universitas Kimia FMIPA Keputih. Surabaya.

Wahyuni, S. 2018. Analisis Efek Temperatur Aktivasi terhadap Daya Adsorpsi Iodin dan Methylen Blue dari Arang Aktif Cangkang Kelapa Sawit. Universitas Halu Oleo. Kendari.

Prasetyo, Y, dan Harun, N. 2013. Penentuan Kosentrasi $\mathrm{ZnCl}$ pada Proses Pembuatan Karbon Aktif Tongkol Jagung dan Penurunan Kosentrasi Surfaktan Liniar Alkyl Benzene Sulphonate (LAS). UNESA. Journal of Chemistry, 2 (3):8-13.

Rahmayani, F, dan Siswarni, M, Z. 2013. Pemanfaatan Batang Jagung Sebagai Adsorben Alternatif pada Pengurangan Kadar Klorin dalam Air Olahan (Treated Water). Jurnal Tekhnik Kimia, 2(2): 1-5. 
Ranada, V. 2015. The Effect of Carbonization Temperature Variation to the Adsorption Ability of Rubber Fruit Shell Activated Carbon. Prosiding Semirata Bidang MIPA BKS-PTN barat. Universitas Tanjung Pura. Pontianak : 294-303.

Widodo, B. 2008. Analisis Sifat Mekanik Komposit Epoksi dengan Penguat Serat Pohon Aren (Ijuk) Model Lamina Berorientasi Sudut Acak (Random). Institut Teknologi Nasional. Malang. 